\title{
PHYTOPATHOGENIC FUNGI ASSOCIATED WITH RIPENING FRUIT OF DATE PALM (PHOENIX DACTYLIFERA L.) DURING RAINY SEASON IN THE UNIVERSITY AREA OF KHAIRPUR, SINDH, PAKISTAN
}

\author{
Mirza Hussain ${ }^{1}$, Noor Jehan Ismaili ${ }^{2}$ \\ ${ }^{1}$ Department of Botany, Government Girls Degree Science College, Gambat, Pakistan. \\ ${ }^{2}$ Shah Abdul Latif University, Khairpur, Pakistan.
}

\section{ART I C L E I N F O}

\section{Article history}

Received: June 12, 2019

Revised: September 28, 2019

Accepted: December 15, 2019

\section{Keywords}

Rainfall

Ripening stage

Airborne fungi

Dates fruit

Corresponding Author: Mirza Hussain

Email: mirzasamo512@gmail.com

(C) 2019 EScience Press. All rights reserved.
In Khairpur, dates crop is damaged during rainy months of June, July and August as the rainy season provides favorable conditions for most of the microorganisms. Amongst different microorganisms, fungi are known as the severest pathogens. In the present study, phytopathogenic fungi associated with ripening fruits of different varieties of dates (Aseel, Khar and Kupro) were isolated and characterized. Three fungi viz. Aspergillus flavus, Penicillium expansum and Alternaria tenuis were isolated from the ripening fruits of date varieties. The fungus P. expansum was isolated from Kupro, A. tenuis from Aseel and A. flavus from Kupro.

\section{INTRODUCTION}

Date palm (Phoenix dactylifera L.) is considered as one of the oldest and main staple and ancient crops of the world (Abro et al., 1986; Al-Harrasi et al., 2014). It is commercially, economically, nutritionally and medicinally the most important crop (Ahmed and Farooqi, 1972; Ishtique and Tarique, 1988; Khuskh, 1988). Fungal diseases on date palm are of great importance and interest because date fruit contains essential nutrients and serves as good medium for several fungal species for their luxuriant growth (Ismailli et al., 2003). Dates are easily spoilt during rainy season when climatic conditions are highly humid (Hussain, 2012; Ismailli et al., 1993; Mahar, 1998; Mahar and Bhatti, 1994). A great deal of fungi affect date palm production due to environmental changes. Date palm trees are attacked by a number of pathogens under favorable environmental conditions, which cause serious damages (Chaughtai, 1986; Sharma and Mukerji, 1976). The diseases play a negative role in agriculture. About $16 \%$ i.e. 550 million tons of total crop production in the world is lost per annum due to fungal diseases. It is well known that this cash and prominent crop of district Khairpur suffers serious losses in yield and quality as a result of date fruit pathogens due to rain falling. It was also pointed out that the weather factors affected host and pathogen in a complex way during disease development. Diurnal and seasonal variations of weather of a particular locality influence the incidence of diseases by airborne fungal pathogens. Importance of rain and rain splash in the dispersal and infection process has been emphasized (Ismailli, 1999). Rain is a 
chief trouble in date palm growing countries but in district Khairpur of Sindh, Pakistan, an occasional monsoonal rain fall occurs during the month of July to August and causes heavy damage to the mature crop of dates. The humidity is at the maximum during the monsoonal months of July to September and increases the damage by creating conditions favorable for microorganisms such as yeasts, fungi and bacteria etc. Amongst microorganisms, the fungi are causing more damages to crops. In Khairpur district, fungal infection is the major problem wherever the date palms are grown and incurs a considerable loss to date's crop. Keeping in view the above mentioned facts, in the present study, fungi infecting dates during the monsoon were isolated and identified with the objective to suggest control strategies to cure these fungi.

\section{MATERIALS AND METHODS}

Samples of infected date fruits (figure 1) of different varieties i.e. Aseel, Khar and Kupro were collected from the experimental area at ripening stage with the help of sterilized forceps into polythene bags. The samples were brought to the laboratory for isolation and identification of fungal pathogens (Soomro, 1990). Czepek's Dox Agar medium was used for the isolation of fungal pathogens. The medium in the Petri plates was inoculated with the infected parts of date fruits. The inoculated plates were incubated at $29^{\circ} \mathrm{C}$ for 7 days. The individual colonies were picked and placed on fresh medium in the Petri plates for purification of the fungi (figure 2). The fungi were identified on the basis of different keys (Al-Yasiri et al., 2010; Cook, 1963; Gilman, 1975; Maitlo et al., 2013; Markhand et al., 2010; Thom and Raper, 1945).

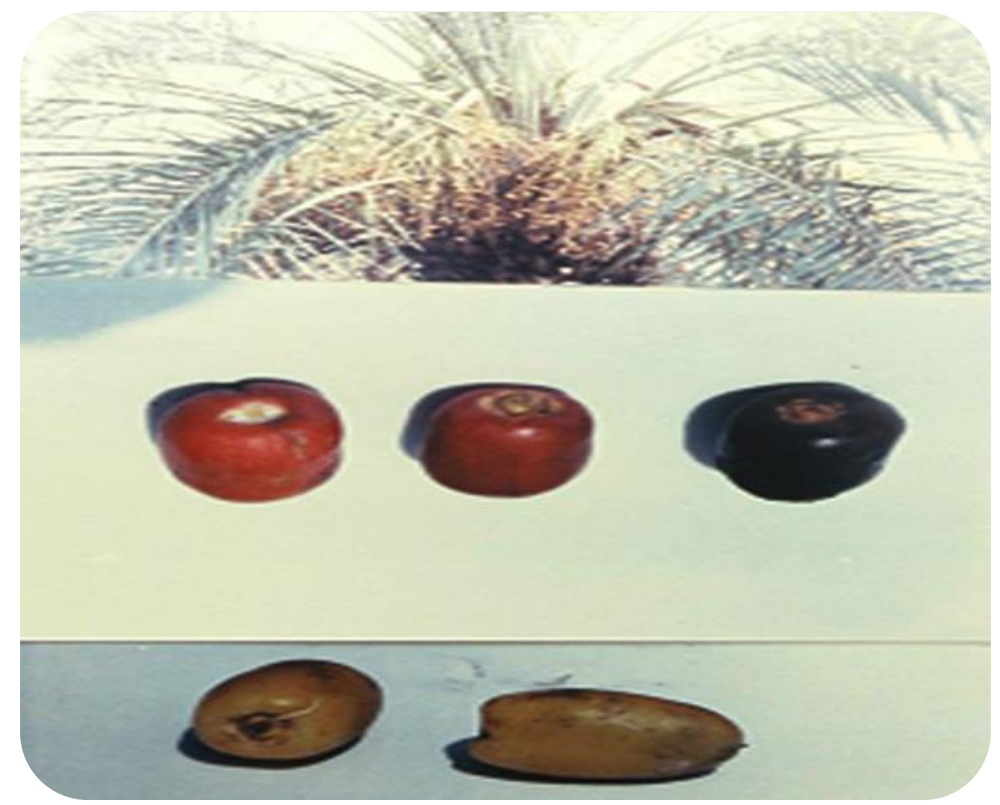

Figure 1. Infected dates with different fungi.
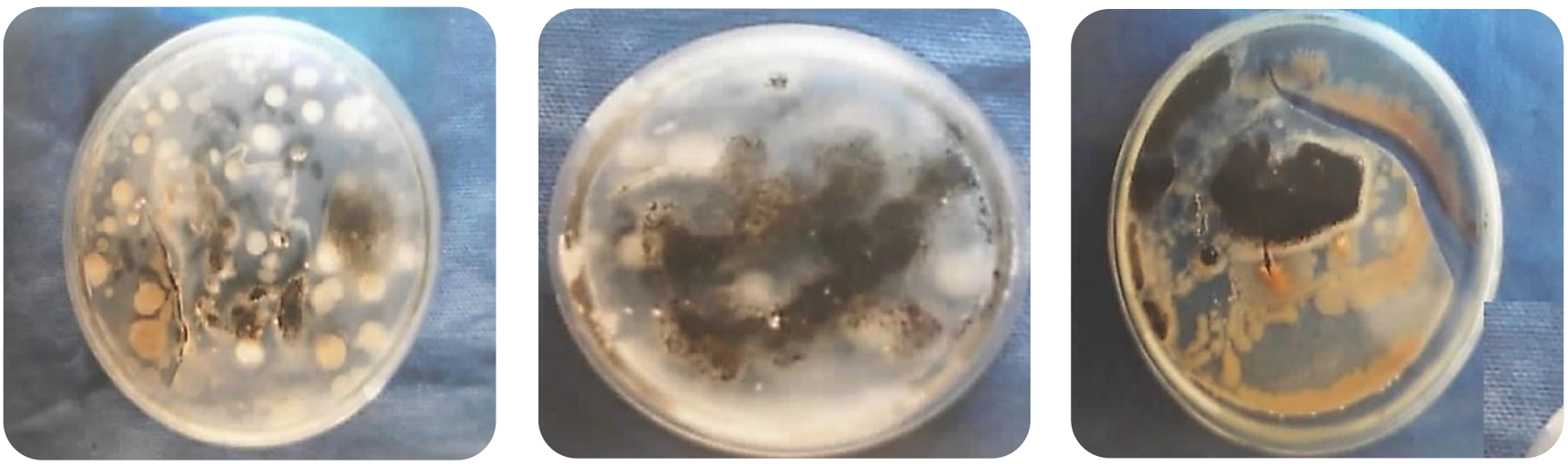

Figure 2. Growth of different fungi on growth media. 


\section{RESULTS AND DISCUSSION}

On the basis of morphological characters, three fungi viz. Aspergillus flavus, Penicillium expansum and Alternaria tenuis were isolated and identified from the ripening fruits of date varieties. The fungus $P$. expansum was isolated from Kupro, A. tenuis from Aseel and A. flavus from Kupro (figure 3, 4, 5). The overall frequency of these three fungi is given in figure 6 .
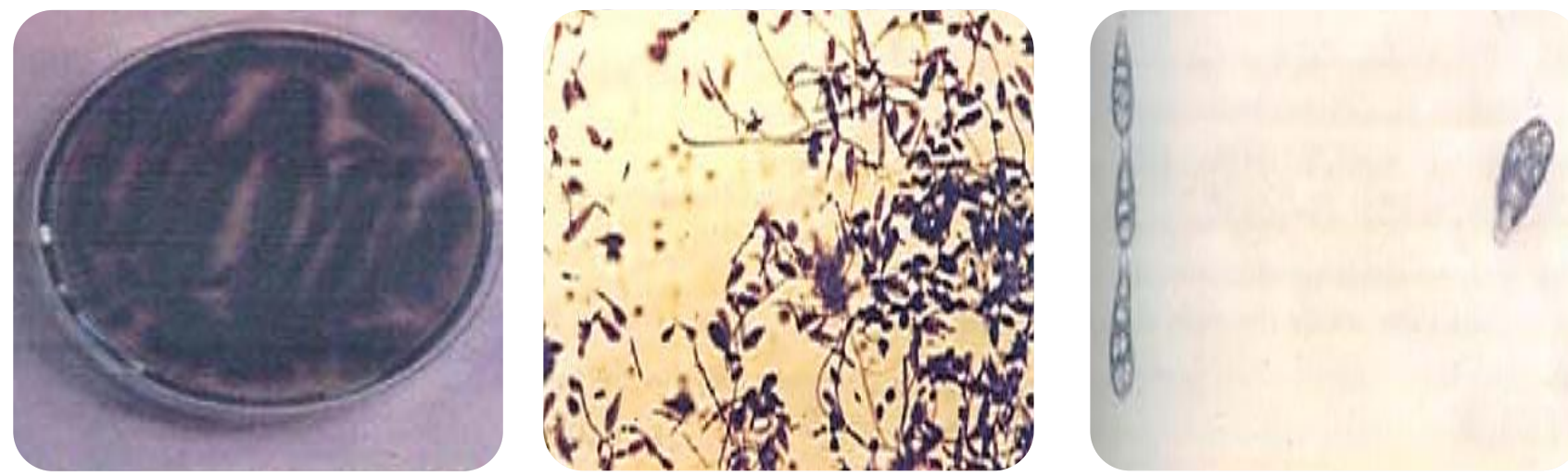

Figure 3. A: Colon of Alternaria tenuis on Czpek's Dox Medium. B: Fungal hyphae and condiophores. C: Conidia of the fungus.
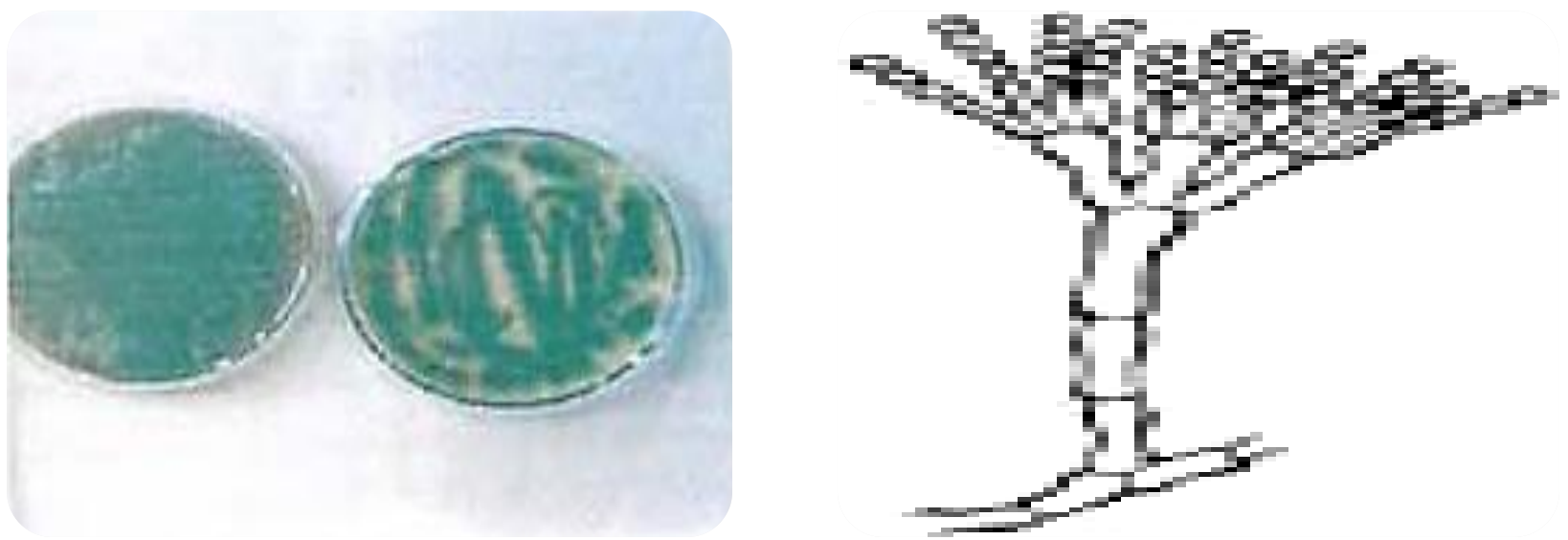

Figure 4. A: Colony of Penicillium expansum on Czpek's dox medium. B: conidlophores
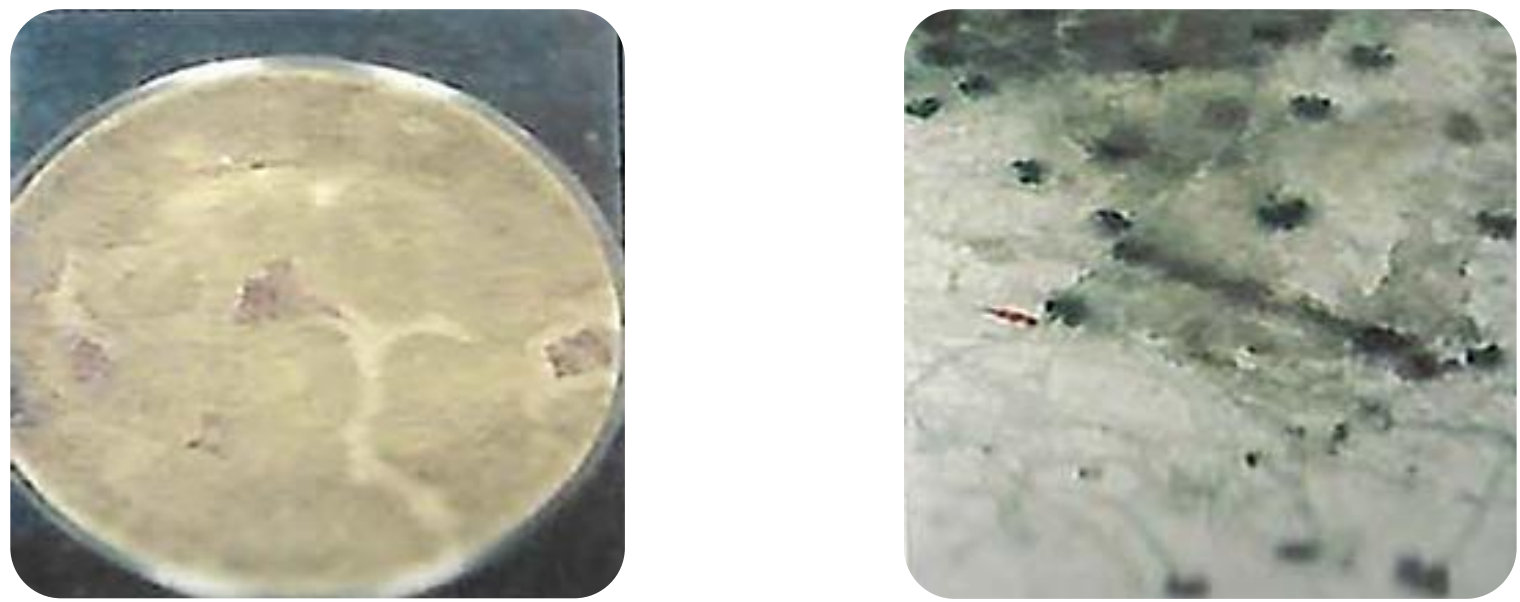

Figure 5. A: Colony of Aspergillus flavus on Czpek's Dox Medium B: Conidiophores with conidia 


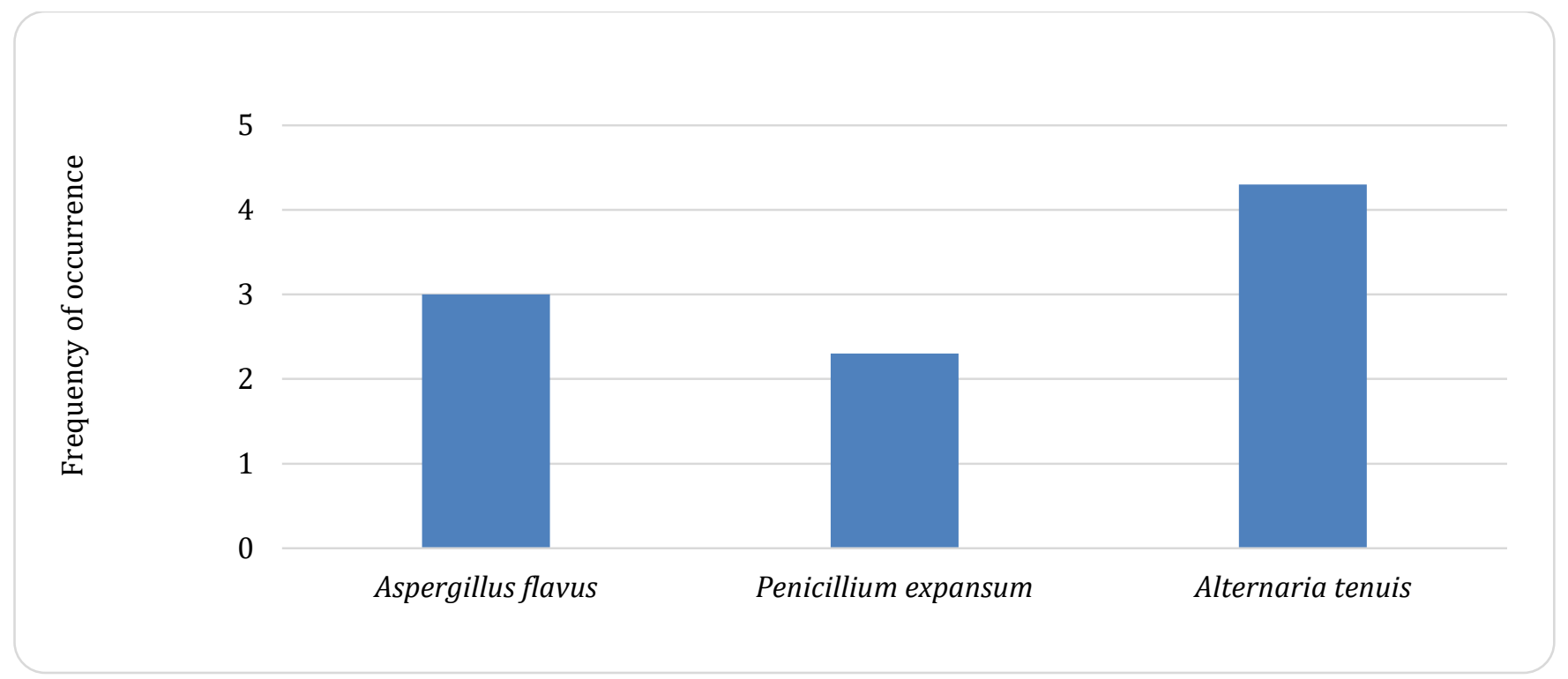

Figure 6. The overall frequency of occurrence of different fungi in Khairpur.

The role of rainfalls was also investigated on the prevalence of fungal pathogen. The minimum humidity of $21 \%$ was recorded during March and April whether it was the maximum during rainy season. The high humidity resulted in the increase in the prevalence of these fungi by creating favorable conditions for the fungi. It is concluded that the incidence and prevalence of fungal pathogens is greatly increased during rainy season which demand stringent surveillance and control measures to minimize the damage (Markhand et al., 2013).

Authors' contribution: $\mathrm{MH}$ and NJI conceived and designed the study; $\mathrm{MH}$ conducted the research work and wrote the initial draft; $\mathrm{MH}$ and NJI reviewed and edited the manuscript.

Conflict of Interest: The authors declare no conflict of interest.

\section{REFERENCES}

Abro, H.W., Sheikh, M., Khan, M., 1986. Studies or aerial mycoflora or the university campus area, Sindh University. Research Journal Science Series. 18, 185-186.

Ahmed, S., Farooqi, W.A., 1972. Studies on some distinguishing characters of Iraqi dates at Jhang. Punjab Fruit Journal (Date Palm Number). 33, 136-147.

Al-Harrasi, A., Rehman, N.U., Hussain, J., Khan, A.L., AlRawahi, A., Gilani, S.A., Al-Broumi, M., Ali, L., 2014. Nutritional assessment and antioxidant analysis of
22 date palm (Phoenix dactylifera) varieties growing in Sultanate of Oman. Asian Pacific Journal of Tropical Medicine 7, 591-598.

Al-Yasiri, I.I., Saad, N.A., Nasser, A.R., Hassan, S.A., Zaid, K.M., 2010. The relationship between the fungus Fusarium solani and some pathological phenomena on date palm tree and the effectiveness of some systemic fungicides for their control., IV International Date Palm Conference 882, pp. 505-514.

Chaughtai, G.H., 1986. Annual report of insects pests of date palm \& their control at D.I. Khan. Sindh Journal of Agriculture, 1-6.

Cook, W.B., 1963. A laboratory guide to fungi of polluted water, sewage and sewage system. Cincinnati Public Health Services, 1.

Gilman, J.C., 1975. A manual of soil fungi. IOWA State College Press, USA.

Hussain, M., 2012. Impact of rainfall (humidity) on the development of fungal diseases on date plam (Phoenix dactylifer L.) fruit at ripening stage at district khairpur Sindh, Pakistan. University of Sindh, pp. 103-105.

Ishtique, M., Tarique, M., 1988. A physical propritress of fruit some indigence date palm cultivars \& grown at D.I. KHAN Sarhad Journal of Agriculture 4, 2271-2275.

Ismailli, N.J., 1999. Morphological and biochemical studies in dates at Khairpur. University of Sindh, 
pp. 87-88.

Ismailli, N.J., Muhammad, S., Zardari, M., 2003. Fungi occurring on dates (Phoenix dactytifera L) fruit during the rainy season in Khairpur district Sindh, Pakistan. Scientific Khyber 4 110-111.

Ismailli, N.J., Soomro, A.Q., Zardari, M., Memon, M.S., Soomro, I., 1993. Fungi occurring on date palm, leaflets and inflorescence during rainy season in Khairpur Scientific Sindh Annual Journal of Research 1-9.

Khuskh, M.K., 1988. Role of different constituents in the development of date fruit of Khairpur district. . University of Sindh, pp. 37-39.

Mahar, A.Q., 1998. Protection of date palm (Phoenix dactyllifera L. ) from monsoonic rain some measures in a district Khairpur, Sindh, Pakistan. Scientific Sindh 7-8.

Mahar, A.Q., Bhatti, N.M., 1994. Protection of date palm (Phoenicx dactylifera $\mathrm{L}$.) from moonsoonic rains in district Khairpur, Sindh, Pakistan. Scientific Sindh 2, 85-93.

Maitlo, W.A., Markhand, G.S., Abul-Soad, A.A., Lodhi, A.M.,
Jatoi, M.A., 2013. Chemical control of Fusarium solani causing sudden decline of date palm in Khairpur, Pakistan. Pakistan Journal of Botany 45, 7-11.

Markhand, G.S., Abul-Soad, A., Jatoi, M., 2013. Chemical control of sudden decline disease of date palm (Phoenix dactylifera L.) in Sindh, Pakistan. Pakistan Journal of Botany 45, 7-11.

Markhand, G.S., Abul-Soad, A.A., Mirbahar, A.A., Kanhar, N.A., 2010. Fruit characterization of Pakistani dates. Pakistan Journal of Botany 42, 3715-3722.

Sharma, K.R., Mukerji, K.G., 1976. Microbial ecology of Sesamum orientale L. and Gossypium hirsutum L., Microbiology of Aerial Plant Surfaces. Elsevier, pp. 375-390.

Soomro, I.A., 1990. Isolation and identification of dermatophytey and other keratinophilic fungi from the soil of Shah Abdul Latif University Khairpur Sindh Pakistan. Scientific Khyber, 3 175182.

Thom, C., Raper, K.B.A., 1945. Manual of the Aspergillius, The William and Wikins Co. Baltimore. 